\title{
Supplementation with different non-fiber carbohydrate sources in dairy cow diets with high or low rumen-undegradable protein content
}

\author{
[Suplementação com diferentes fontes de carboidratos não fibrosos em dietas \\ para vacas leiteiras com alto ou baixo teor de proteína não \\ degradável no rúmen] \\ J.P.P. Oliveira ${ }^{1}$, A.F. Bicalho ${ }^{1}$, V.M.R. Malacco $^{1 *}$, C.F.A. Lage $^{1}$, H.M. Saturnino ${ }^{1}$, \\ S.G. Coelho ${ }^{1}$, B.M. Sousa ${ }^{2}$, J.P.P. Rodrigues ${ }^{3}$, R.B. Reis ${ }^{1}$ \\ ${ }^{1}$ Escola de Veterinária - Universidade Federal de Minas Gerais - Belo Horizonte, MG \\ ${ }^{2}$ Centro Universitário - UNIBH - Belo Horizonte, MG \\ ${ }^{3}$ Universidade Federal de Viçosa - Viçosa, MG
}

\begin{abstract}
The objective for this study was to evaluate the supplementation with different non-fibrous carbohydrate (NFC) sources for grazing dairy cows in diets with high or low concentrations of rumen undegradable protein (RUP). Twelve multiparous cows averaging $30 \mathrm{~kg} / \mathrm{d}$ of milk production and $45 \pm 23$ days in milk in a $4 \times 4$ Latin square design with $2 \times 2$ factorial arrangement were used. The difference in NFC content of the diets was achieved using ground corn (GC) or dried citrus pulp (DCP). Dietary RUP was altered by the partial replacement of soybean meal (LRUP) by roasted whole soybean and corn gluten meal (HRUP). Greater dry matter intake (DMI) was observed in DCP treatments compared to GC treatments (19.2 and $17.7 \mathrm{~kg}$ /day of DM, respectively). Milk fat concentration was lower for LRUP treatments $(3.4 \%)$ when compared to HRUP (3.6\%). The milk protein concentration was greater for GC treatments $(2.9 \%)$ in relation to DCP treatments $(2.8 \%)$. Lower milk ureic nitrogen was observed when DCP diets were fed compared to those with GC (17.8 and $21.2 \mathrm{mg} / \mathrm{dL}$, respectively). The use of DCP as CNF source increased dry matter intake as well as milk fat concentration, although no differences in milk production were observed for RUP level.
\end{abstract}

Keyword: milk production, pectin, panicum maximum, RDP, starch

\section{RESUMO}

Objetivou-se avaliar a suplementação com diferentes fontes de carboidratos não fibrosos (CNF) em vacas manejadas a pasto em dietas com alta ou baixa concentração de proteína não degradável no rúmen (PNDR). Doze vacas multíparas com média de $30 \mathrm{~kg}$ leitel dia e $45 \pm 23$ dias em lactação foram utilizadas em delineamento quadrado latino $4 \times 4$ com arranjo fatorial $2 \times 2$. As fontes de CNF foram milho moído (MM) e polpa cítrica seca (PC). A PNDR da dieta foi alterada pela substituição parcial do farelo de soja da dieta de baixa PNDR (BPNDR) por grão de soja tostado e farelo de glúten de milho dieta de alta PNDR (APNDR). Foi observado maior consumo de matéria seca (CMS) nos tratamentos com PC quando comparado aos tratamentos com MM (19,2 e 17,7kg / dia de $M S$, respectivamente). O teor de gordura do leite foi menor para os tratamentos com BPNDR (3,4\%) em comparação aos tratamentos com APNDR $(3,6 \%)$. O teor de proteína do leite foi maior nos tratamentos com MM $(2,9 \%)$ em relação aos tratamentos com PC (2,8\%). Foram observados menores teores de nitrogênio ureico no leite dos animais alimentados com PC em relação aos com MM (17,8 e 21,2mg / dL, respectivamente). O uso de PC como fonte de CNF aumentou o consumo de matéria seca, bem como o teor de gordura do leite, embora não tenham sido observadas diferenças na produção de leite relacionada a alteração nos teores de PNDR.

Palavras-chave: produção de leite, pectina, panicum maximum, RDP, amido

Recebido em 16 de maio de 2018

Aceito em 11 de julho de 2019

*Autor para correspondência (corresponding author)

E-mail: malacco.victor@yahoo.com.br 


\section{INTRODUCTION}

In pasture-based dairy systems low dry matter intake (DMI) is a major limitation to productivity and, because of that, supplementation is essential to support the high milk output per cow (Brito et al., 2017). Cereal grains make up the largest part of the supplements used in these systems. Sources of non-fibrous carbohydrates (NFC) with high ruminal degradability such as corn are characterized by enhancing propionate concentration, and therefore optimize the efficient use of energy and nitrogen (Bargo et al., 2003; Mulligan et al., 2004).

Nevertheless, starch-based concentrate can reduce ruminal $\mathrm{pH}$ and pasture ruminal digestion, likely leading to an increasing retention time of feed in the rumen and decrease pasture DMI (Bargo et al., 2003) when provided to animals receiving highly degradable pasture-based diet.

An increase in the cost of corn grain has sparked the interest in formulating diets that partially replace ground with another $\mathrm{CNF}$ source, such as dried citrus pulp (Fredin et al., 2015). Dried citrus pulp is a byproduct obtained from the industrial extraction of orange juice or other citric products (Bampidis and Robinson, 2006). This byproduct contains high sugar (120 to $400 \mathrm{~g} / \mathrm{kg}$ of total DM) and high neutral detergent-soluble fiber (NSDF) contents originated from pectic substances (250 to $440 \mathrm{~g} / \mathrm{kg}$ of DM) (Hall et al., 2010).

In diets with high quality-tropical grass inclusion, crude protein (CP) is usually not limiting, however, the fast nitrogen availability from the soluble protein fraction combined with a slower carbohydrate fermentation in the rumen, results in a reduced $\mathrm{N}$ assimilation by the microbial mass (Schor and Gagliostro, 2001). Due to the unsynchronized supply of nitrogen and energy, microbial flow can be reduced and consequently the post ruminal amino acids (AA) supply might be compromised and affect milk production. Different sources of NFC have different fermentation profiles, yielding different proportions of volatile fatty acid affecting microbial protein yield differently (Hristoy and Ropp, 2003).
Overall, pasture-based diets have a high proportion of RDP, which can limit the production of high milk yield cows. Supplementation of protein sources that contain high RUP might increase the efficiency of $\mathrm{N}$ use and milk production in grazing dairy cows (Bargo et al., 2003; Silva, 2013). The objective of this study was to evaluate the effects of supplementation with different non-fibrous carbohydrate (NFC) sources in the diets, with high or low concentrations of rumen undegradable protein (RUP), on milk production and composition, nitrogen use and feed efficiency in lactating dairy cows under rotational grazing system (Panicum maximum cv. Mombaça).

\section{MATERIAL AND METHODS}

The protocols for this study were approved by the Ethics Committee of the Universidade Federal de Minas Gerais (UFMG; protocol no, 057/2009). The experiment was performed at a commercial farm in Minas Gerais, Brazil. Twelve Holstein X Gyr (F1) multiparous cows averaging 30kg/d of milk, $535 \pm 18 \mathrm{~kg}$ of body weight, and $45 \pm 23$ days in milk (DIM), at the beginning of the study, were used.

The design was a $4 \times 4$ Latin square with $21-d$ periods and a $2 \times 2$ factorial arrangement of treatments. Samples and data were collected in the last $7 \mathrm{~d}$ of each period. The difference in NFC content of the diets was achieved using ground corn (GC; starch) or dried citrus pulp (DCP sugar and pectin). Dietary RUP was altered providing the partial replacement of soybean meal (LRUP) by roasted whole soybean and corn gluten meal (HRUP). Diets were balanced according to the National Research Council (Nutrients..., 2001) to meet the cow's requirements and to be isonitrogenous and to have a similar NFC concentration (Table 1).

The animals were kept under rotational grazing in paddocks of Panicum maximum cv. Mombaça with a day of occupation at a variable stocking rate from 10 to 12 cows/ha. After each grazing cycle, the paddocks were fertilized with $50 \mathrm{~kg}$ of N/ha. Light interception at $95 \%$ determined the rest period, using the recommendations for entrance height $(90 \mathrm{~cm})$ and exit height $(50 \mathrm{~cm})$. 
Table 1. Ingredients and chemical composition of experimental diets

\begin{tabular}{|c|c|c|c|c|}
\hline \multirow[b]{3}{*}{ Item } & \multicolumn{4}{|c|}{ Experimental diets $^{1}$} \\
\hline & \multicolumn{2}{|c|}{ GC } & \multicolumn{2}{|c|}{ DCP } \\
\hline & HRUP & LRUP & HRUP & LRUP \\
\hline \multicolumn{5}{|c|}{ Components (kg of DM/d) } \\
\hline Mombaça & 8.50 & 8.50 & 8.50 & 8.50 \\
\hline Citrus pulp & 0.00 & 0.0 & 7.05 & 7.51 \\
\hline Graund corn & 7.48 & 7.66 & 0.00 & 0.00 \\
\hline Cottonseed & 0.64 & 1.93 & 0.55 & 2.02 \\
\hline Soybean meal & 1.32 & 2.02 & 0.62 & 2.33 \\
\hline Corn gluten meal & 0.41 & 0.00 & 0.77 & 0.00 \\
\hline Roasted soybean & 0.73 & 0.00 & 1.41 & 0.00 \\
\hline Urea & 0.00 & 0.09 & 0.00 & 0.02 \\
\hline Molasses & 0.30 & 0.30 & 0.30 & 0.30 \\
\hline Mineral premix & 0.53 & 0.53 & 0.53 & 0.53 \\
\hline Salt & 0.05 & 0.05 & 0.05 & 0.05 \\
\hline Limestone & 0.10 & 0.10 & 0.00 & 0.00 \\
\hline Total & 20.06 & 20.29 & 19.78 & 21.28 \\
\hline \multicolumn{5}{|c|}{ Chemical composition $(\% \text { of DM })^{2}$} \\
\hline $\mathrm{CP}$ & 16.80 & 16.80 & 16.80 & 16.80 \\
\hline RDP & 59.90 & 66.70 & 60.00 & 67.00 \\
\hline RUP & 40.10 & 33.30 & 40.00 & 33.00 \\
\hline TDN & 71.20 & 71.00 & 67.40 & 68.60 \\
\hline $\mathrm{ADF}$ & 20.00 & 20.70 & 26.80 & 27.40 \\
\hline NDF & 40.10 & 40.90 & 43.90 & 43.90 \\
\hline NFC & 33.00 & 34.00 & 28.70 & 28.70 \\
\hline $\mathrm{EE}$ & 3.60 & 3.70 & 3.90 & 3.70 \\
\hline $\mathrm{Ca}$ & 0.73 & 0.72 & 1.24 & 1.21 \\
\hline $\mathrm{P}$ & 0.44 & 0.45 & 0.39 & 0.43 \\
\hline
\end{tabular}

${ }^{1}$ GC-HRUP: Diet corn high RUP; GC-LRUP: Diet corn low RUP; DCP-HRUP: Diet citrus pulp high RUP; DCPLRUP: Diet citrus pulp low RUP.

${ }^{2} \mathrm{DM}$ : dry matter; CB: crude protein; RDP: rumen-degradable protein; RUP: rumen-undegradable protein; NDF: neutral detergent fiber; ADF: acid detergent fiber; TDN: total digestible nutrients NFC: non-fiber carbohydrate; EE: Ether extract.

The supplementation with concentrate was done individually in the feeding lane with headlock, three times a day: after milking in the morning (0530hrs), at $1200 \mathrm{~h}$ and after milking in the afternoon $(1630 \mathrm{hrs})$. At noon the animals were brought from pasture for supplementation. After feeding they were moved to a shaded resting area with available water where they stayed until the afternoon milking.

The forage availability in each paddock was estimated twice a week, prior to the beginning of each grazing cycle, by cutting the pasture to $50 \mathrm{~cm}$ in height (potentially edible biomass). A frame of $1 \mathrm{~m}^{2}$ was randomly placed on the paddock at six different points for sampling (Penati, 2002). Pasture samples were dried in a forced-air oven at $55^{\circ} \mathrm{C}$ for $72 \mathrm{hrs}$, ground through a $1-\mathrm{mm}$ screen (Wiley mill; Arthur H. Thomas, Philadelphia,
PA). At the end of the trial, a composite sample was made for each experimental period and ingredients, using the same amount for each sample and then stored at room temperature until the analysis.

Samples from the experimental ingredients and a sample from each concentrate after a new mixture were collected once per period. All samples were stored at $-20^{\circ} \mathrm{C}$ until analysis. Samples were predried in a forced-air oven at $55^{\circ} \mathrm{C}$ for $72 \mathrm{hrs}$, and DM results were adjusted to $100^{\circ} \mathrm{C}$, according to the American Organization of Analytical Chemists (AOAC) International (2012; method 925.40). All samples were ground using a Wiley mill through a 1-mm screen (Arthur H. Thomas, Philadelphia, PA). At the end of the trial, a composite sample was made for each experimental period and ingredients, using the 
same amount for each sample, which were analyzed for $\mathrm{CP}$ content using the Kjeldahl method (AOAC International, 2012, method 955.04), ether extract (AOAC International, 2012, method 920.39), and ash concentration, determined at $550{ }^{\circ} \mathrm{C}$ (AOAC International, 2012; method 942.05).

Neutral detergent fiber (NDF), acid detergent fiber (ADF), and lignin were determined according to Van Soest et al. (1991). NDF was not correct for the residual ash. Amylase was used in concentrate ingredients in the analysis. Non-fiber carbohydrate was calculated as $100-[\mathrm{CP}+\mathrm{NDF}$ + ether extract + ash]. The concentration of rumen degradable protein (RDP), RUP, total digestible nutrients was estimated by NRC (Nutrient..., 2001), based on the observed DMI, milk production and composition, and cow's BW. The analysis of protein fraction of forage was determined. The NPN (NH3, TAA and oligopeptides) (fraction A) was determined using a semi-automated method (Colombini et al, 2011) modified to include automated data collection. Soluble crude protein N (fraction B1) was determined using a modification of the method of Licitra et al. (1996). Fraction C was the nitrogen found in acid detergent fiber (ADIN). Fraction B3 was calculated as the difference between the $\mathrm{CP}$ recovered in neutral detergent fiber (NDIN) and ADIN. Fraction B2 was the total CP minus the sum of fractions $\mathrm{A}, \mathrm{B} 1, \mathrm{~B} 3$ and $\mathrm{C}$.

Milk production was determined on the 17 th and 18th day of the experimental period, with two daily measurements at $0500 \mathrm{hrs}$ and $1700 \mathrm{hrs}$ during milking using intravenous oxytocin (2IU/milking) (UCBVET®, Jaboticabal, SP, Brazil). Samples of milk per cow were collected in plastic bottles containing preservative (2-bromo-2-nitropropane-1,3-diol $10 \mathrm{mg} / 50 \mathrm{~mL} / \mathrm{milk}$ ) in four consecutive milkings using a milk collector coupled to the milk-line (GEA®, Düsseldorf, Germany). Milk samples were stored and analyzed for milk fat, total protein by infrared analyses ((Bentley 2000 - Bentley Instruments Inc., Chaska, MN) and milk urea nitrogen (MUN) by Fourier Transform Infrared methodology (CombiScope FTIR advanced / Delta Instruments, Drachten, Netherlands) (Oliveira a et al., 2012). Milk production corrected for $35 \mathrm{~g} / \mathrm{kg}$ of fat (FCM3.5) was obtained using the equation proposed by Gaines $(1928):$ FCM $3.5=(0.5255 \times$ MP $)+(16.425 \times$
FatP), in which LCG3.5 is the milk production corrected for $35 \mathrm{~g} / \mathrm{kg}$ of fat $(\mathrm{Kg} /$ day $)$; $\mathrm{MP}$ is the milk production ( $\mathrm{kg} /$ day); FatP is the fat production (kg/day).

For the determination of fecal production (FP), external marker (modified enriched hydroxyphenylpropane LIPE) was used as described by Saliba et al. (2015), provided orally at $0.5 \mathrm{~g} / \mathrm{cow} /$ day for seven consecutive days, from 14th to 21thday of each experimental period. To determine the daily DM intake the indirect method was used as described by Burns et al. (1994), based on the relationship between the estimations of FP and digestibility estimated by the internal indicator indigestible NDF (iNDF). Fecal collection (approximately 500g/animal) was performed twice a day $(0600 \mathrm{~h}$ and $1700 \mathrm{~h})$ as described by Barros et al. (2009), directly from the rectum of the cows, from the 17 th to the $21 \mathrm{st}$ day of the experimental period totaling ten samples per animal as described by Saliba et al. (2015).

Two spot urine samples were collected on the 15th and 16th days of each period when the cows were held to receive the concentrate supplementation (0700h) as described by Chizzotti et al. (2008). A $5 \mathrm{~mL}$ aliquot of urine was diluted in $45 \mathrm{~mL}$ of a solution containing $0.036 \mathrm{~N}$ sulfuric acid and stored at $10^{\circ} \mathrm{C}$. At the end of the experiment, the urine samples were thawed for the preparation of a composed sample per cow and per period for the quantification of purine derivatives (uric acid and allantoin), creatinine and nitrogen. An aliquot was analyzed for the determination of creatinine by the colorimetric system with end point reaction, using picrate and an acidifier, using commercial kits (K016 Bioclin/Quibasa, Belo Horizonte, MG, Brazil). Uric acid in urine samples were determined by enzymatic colorimetric method (UOD-PAP) using a standard diagnostic kit (K139 Bioclin/Quibasa, Belo Horizonte, MG, Brazil) according to manufacturer's instructions. Readings were acquired using the Cobas Mira clinical analyzer (Global Medical Instrumentations, Inc., Ramsey, MN, USA). The nitrogen content of the urine was obtained by the Kjeldahl method (AOAC, 1990). The concentration of allantoin was determined by the technique described by Chen and Gomes (1992) and the absorbance was analyzed by colorimetric at $522 \mathrm{~nm}$. 
The urinary volume was calculated according to the equation proposed by Magalhães et al. (2005), using the mean daily creatinine excretion as a function of the body weight of the animal obtained by Chizzotti et al. (2004), which is $24.05 \mathrm{mg} / \mathrm{kg}$ $\mathrm{BW} /$ day, and the creatinine concentration in the sample (mg/L).

Individual blood samples were taken from coccygeal vein or artery on the 21 st day of the experimental period, once, three hours after the concentrate supply. The blood was centrifuged at $3000 \mathrm{x} g$ for 15 minutes and the plasma was frozen in Eppendorf microtubes (Bioplast ${ }^{\circledR}$, Rio de Janeiro, RJ, Brazil) for further analysis. Urea were determined by the enzymatic colorimetric method (UV (GLDH)) using a standard diagnostic kit (1070250K Synermed International Inc., Westfield, IN, USA). Readings were acquired using the Cobas Mira clinical analyzer (Global Medical Instrumentations, Inc., Ramsey, MN, USA).

All data were analyzed with the MIXED procedure of SAS (SAS Institute, 2001). The statistical analysis for intake, digestibility, milk production and composition, excretion of purine derivatives, nitrogen balance, plasmatic glucose and nitrogen were performed by the mixed model in a Latin square. In the following iteration, unfolding of RUP content and carbohydrate source was carried out. Analysis of contrast between the source of carbohydrate and the RUP content were also performed. Data were analyzed using the following fitted model:

$$
\begin{aligned}
& \mathrm{Y}_{\mathrm{ijklm}}=\mu+\mathrm{A}_{\mathrm{i}}+\mathrm{P}_{\mathrm{j}}+\mathrm{Q}_{\mathrm{k}}+\mathrm{FC}_{\mathrm{l}}+\mathrm{NP}_{\mathrm{m}}+\mathrm{FNL}_{\mathrm{n}}+ \\
& \varepsilon_{i j k l m n}
\end{aligned}
$$

Where Yijklm is the dependent variable, $\mu$ is the overall mean, $A_{i}$ is the animal effect, $P_{j}$ is the effect of period $\mathrm{j}$ ( $\mathrm{j}=1$ to 4 ), $\mathrm{Q}_{\mathrm{k}}$ is the fixed effect of Latin square ( $\mathrm{k}=1$ to 3 ); $\mathrm{FC}_{1}$ is the effect of carbohydrate source ( $1=$ GC and DCP), $\mathrm{NP}_{\mathrm{m}}$ is the effect of RUP content ( $\mathrm{m}=$ low or high); $\mathrm{FNL}_{\mathrm{n}}$ is the effect of interaction by RUP level and carbohydrate source, $\varepsilon_{i j k l m n}$ is the random model error. Means of the tested variables were analyzed using the Student's t-test. Significance levels were considered at $\mathrm{P} \leq 0.05$ and tendency levels as 0.05 $<\mathrm{P}<0.10$.

\section{RESULTS AND DISCUSSION}

Forage entrance heights, chemical composition and protein fraction average per period are presented in Table 2.

Table 2. Entrance height, chemical composition and forage protein fraction of Panicum Maximum cv Mombaça in the evaluated experimental periods

\begin{tabular}{lcccc}
\hline Item & P1 & P2 & P3 & P4 \\
\hline Entrance height (cm) & 92.5 & 95.0 & 97.5 & 85 \\
Composition & & & & \\
DM,\% & 20.8 & 21.4 & 19.8 & 24.3 \\
CP, \%DM & 19.0 & 20.4 & 15.9 & 18.4 \\
NDF, \%DM & 63.1 & 60.6 & 66.9 & 64.5 \\
ADF, \%DM & 35.7 & 34.6 & 38.9 & 36.9 \\
TDN, \%DM1 & 61.1 & 61.9 & 58.6 & 60.1 \\
Protein fractions \% PB2 & & & \\
A & 17.4 & 19.7 & 20.2 & 17.9 \\
B1+B2 & 32.7 & 36.6 & 29.1 & 30.5 \\
B3 & 44.7 & 39.3 & 45.4 & 46.6 \\
C & 5.2 & 4.4 & 5.3 & 5.0 \\
\hline
\end{tabular}

${ }^{1}$ Calculated by NRC (Nutrient..., 2001) model.

${ }^{2} \mathrm{~A}$ : soluble fraction at time zero of the $\mathrm{CP}$; $\mathrm{B} 1+\mathrm{B} 2$ : soluble fraction of $\mathrm{CP}$ and potentially degradable; $\mathrm{B} 3$ : insoluble fraction at zero time but degradable in the rumen due to the residence time in the rumen; $\mathrm{C}$ : insoluble fraction and not degraded in the rumen.

The crude protein content of the forage in this experiment was higher than previously reported by other authors studying Panicum maximum cv. Mombaça in a rotational grazing system (Cândido et al., 2005; Euclides et al., 2008; Freitas et al., 2019), who reported CP contents in a range of 10.3 to $16.4 \%$ of DM. The CP content of tropical grasses is directly related to the $\mathrm{N}$ fertilization and 
age of maturity at harvest (Alvim et al., 1999; Castagnara et al., 2011). In addition, the content of total digestible nutrients (TDN) were in a range from 58.6 to $61.9 \%$ of DM, which was greater to those found by Balsalobre et al. (2003), showing high nutritional value of the forage provided in this experiment. The highest values were similar to the values of TDN for corn silage and pasture of temperate grasses and legumes intensively handled (Nutrient..., 2001).

The extent and the rate of protein degradation in the rumen are related to the efficiency of $\mathrm{N}$ utilization by the ruminal microorganism. In this study, Fraction B3 was the largest CP fraction in all pasture samples during the study (averaging $44 \%$ of the $\mathrm{CP}$ ). This fraction is characterized by lower rates of degradation in comparison to fractions B1 and B2 because of its association with cell walls. Therefore, a high proportion of fraction B3 escapes ruminal degradation and could be degraded and absorbed in the small intestine. Reis et al. (2010), using tropical grasses from different systems of intensive handling, reported contents of $2.83 ; 4.04 ; 4.09$ and $4.20 \%$ of RUP in relation to CP for Brachiaria brizantha, Cynodon dactylon, Panicum maximum and Pennisetum Purpureum, respectively.

However, the high RUP content observed in some of these grasses does not ensure its availability to be used as metabolizable protein, since RUP might show low intestinal digestibility (25 to 60\%) (Buckner et al., 2013). Total dry mater intake, forage intake, dry matter intake in relation to the live weight and apparent digestibility are presented in Table 3.

Table 3. Total dry matter intake, pasture intake, total intake in $\%$ of body weight and apparent digestibility of Holstein X Gyr (F1) cows in rotational grazing Panicum maximum cv. Mombaça fed with different nonfiber carbohydrates sources in diets with high or low rumen-undegradable protein content

\begin{tabular}{|c|c|c|c|c|c|c|c|c|c|}
\hline \multirow[b]{2}{*}{ Item $^{3}$} & \multicolumn{4}{|l|}{ Diets $^{1}$} & \multirow[b]{2}{*}{$\mathrm{SEM}^{2}$} & \multicolumn{4}{|c|}{$P$-value } \\
\hline & $\begin{array}{l}\text { GC } \\
\text { HRUP }\end{array}$ & $\begin{array}{l}\text { DCP } \\
\text { HRUP }\end{array}$ & $\begin{array}{l}\text { GC } \\
\text { LRUP }\end{array}$ & $\begin{array}{l}\text { DCP } \\
\text { LRUP }\end{array}$ & & $\begin{array}{l}\text { RUP } \\
\text { X GC }\end{array}$ & $\begin{array}{l}\text { RUP X } \\
\text { DCP }\end{array}$ & $\begin{array}{l}\text { NFC X } \\
\text { LRUP }\end{array}$ & $\begin{array}{l}\text { NFC X } \\
\text { HRUP }\end{array}$ \\
\hline TDMI (kg/d) & 18.1 & 19.4 & 17.3 & 19.0 & 0.50 & 0.25 & 0.62 & 0.02 & 0.08 \\
\hline PDMI (kg/d) & 8.8 & 9.4 & 7.9 & 8.4 & 0.57 & 0.24 & 0.20 & 0.54 & 0.48 \\
\hline TDMIPV (\%) & 3.3 & 3.6 & 3.2 & 3.5 & 0.09 & 0.25 & 0.61 & 0.02 & 0.08 \\
\hline $\mathrm{AD}(\%$ of $\mathrm{DM})$ & 66.5 & 67.9 & 64.7 & 67.9 & 0.48 & 0.01 & 0.22 & $<0.01$ & 0.05 \\
\hline
\end{tabular}

${ }^{1}$ CM-HRUP: Diet corn high RUP; CM-LRUP: Diet corn low RUP; CP-HRUP: Diet citrus pulp high RUP; CP-LRUP: Diet citrus pulp low RUP.

${ }^{2}$ Standard error of mean.

${ }^{3}$ TDMI: Total dry matter intake; PDMI: Pasture Dry Matter Intake; TDMIPV: total dry matter intake in relation to the body weight, AD: apparent digestibility.

In LRUP treatments, the source of NFC affected the total dry matter intake (TDMI). Animals fed with DCP-LRUP diets presented greater TDMI and DMI as \% of BW when compared to the animals fed with GC-LRUP $(19.0 \mathrm{~kg} / \mathrm{d} ; 3.5 \%$ and $17.3 \mathrm{~kg} / \mathrm{d} ; 3.2 \%$, respectively). In HRUP treatments, animals fed citrus pulp tended to increase TDMI $(19.4 \mathrm{~kg})$ in relation to animals fed ground corn $(18.1 \mathrm{~kg})$.

The greater TDMI of treatments with the inclusion of citric pulp in relation to the ground corn, independently from RUP content, might occurred due to higher propionate content in the rumen of animals fed GC diets. The cows fed with starch-based diets may suffer inhibition on the intake due to the hypophagic effects of propionate than cows fed with other source of carbohydrate (Allen et al., 2009).

Grovum (1995) suggested that the effects of the infusion of propionate within the reduction of intake are associated to the increase in insulin production by the body. Also, the infusion of propionate in the portal vein of sheep reduced up to $80 \%$ of dry matter intake compared to control (Anil et al., 1993). In agreement with the observed in this study, Clark and Armentano (1997) observed an increase in dry matter intake when beet root replaced $33 \%$ of the milled corn (24.6 
and $23.1 \mathrm{~kg} \mathrm{MS}$ ) in diets of confined cows with alfalfa silage.

No differences $(\mathrm{P}>0.20)$ were observed in the total intake of Panicum maximum cv. Mombaça between the animals fed with the different experimental diets, ranging from 7.9 to $9.5 \mathrm{~kg} \mathrm{DM}$ /day. Apparent digestibility of DM was greater for GC diets when associated with HRUP. The observed results disagree with the theory that an increase in RDP of the diets may lead to greater digestibility of NDF and thus to a greater digestibility of the total DM. However, the data agree with the theory proposed by Hall et al. (2010) that ruminal NDF disappearance is not just a function of the inherent characteristics of the feed but could be affected by characteristics of the entire diet beyond dietary effects in ruminal $\mathrm{pH}$.
Since the NDF is the largest fraction of the diets we can hypothesize that the reduction in the digestibility of the total DM of the GC-HRUP diet may be caused for the alteration in the ruminal $\mathrm{pH}$. These results agree with the increasing in digestibility observed in some studies when pectin-rich feeds (Ben-Ghedalia et al., 1989; Van Vuuren et al., 1993). Hatfield and Weimer (1995) in an in vitro fermentation study showed that citrus pectin although fermented as rapidly as starch, did not depress ruminal $\mathrm{pH}$.

The milk production and composition data are presented in Table 4. Milk production ranged from 29.3 to $30.5 \mathrm{~kg} /$ day, with no significant differences (P> 0.05) between treatments. However, the animals of the CP-HRUP treatment produced $1.2 \mathrm{~kg} /$ day more milk than the CMHRUP treatment.

Table 4. Milk production and composition, plasma urea nitrogen, feed efficiency and $\mathrm{N}$ use of Holstein X Gyr (F1) cows in rotational grazing Panicum maximum cv. Mombaça fed with different non-fiber carbohydrates sources in diets with high or low rumen-undegradable protein content

\begin{tabular}{|c|c|c|c|c|c|c|c|c|c|}
\hline \multirow[b]{2}{*}{ Item $^{2}$} & \multicolumn{4}{|c|}{ Diets $^{1}$} & \multirow[b]{2}{*}{$\mathrm{SEM}^{3}$} & \multicolumn{4}{|c|}{$P$-value } \\
\hline & $\begin{array}{c}\text { GC } \\
\text { HRUP }\end{array}$ & $\begin{array}{c}\text { DCP } \\
\text { HRUP }\end{array}$ & $\begin{array}{c}\text { GC } \\
\text { LRUP }\end{array}$ & $\begin{array}{c}\text { DCP } \\
\text { LRUP }\end{array}$ & & $\begin{array}{l}\text { RUP } \\
\text { X GC }\end{array}$ & $\begin{array}{l}\text { RUP X } \\
\text { DCP }\end{array}$ & $\begin{array}{l}\text { NFC X } \\
\text { LRUP }\end{array}$ & $\begin{array}{l}\text { NFC X } \\
\text { HRUP }\end{array}$ \\
\hline Milk yield, kg/d & 29.3 & 30.5 & 29.8 & 30.0 & 0.49 & 0.53 & 0.41 & 0.80 & 0.09 \\
\hline FCM $3.5, \mathrm{~kg} / \mathrm{d}$ & 29.0 & 30.5 & 29.6 & 31.3 & 0.64 & 0.56 & 0.40 & 0.08 & 0.11 \\
\hline Milk fat, \% & 3.44 & 3.48 & 3.43 & 3.74 & 0.09 & 0.92 & 0.06 & 0.03 & 0.78 \\
\hline Milk fat, $\mathrm{kg} / \mathrm{d}$ & 1.02 & 1.06 & 1.02 & 1.12 & 0.03 & 0.65 & 0.19 & 0.04 & 0.21 \\
\hline Milk protein, $\%$ & 2.93 & 2.77 & 2.93 & 2.79 & 0.02 & 0.99 & 0.38 & $<0.01$ & $<0.01$ \\
\hline Milk protein, $\mathrm{kg} / \mathrm{d}$ & 0.86 & 0.85 & 0.87 & 0.84 & 0.01 & 0.54 & 0.72 & 0.18 & 0.69 \\
\hline MUN, mg/dL & 20.6 & 17.1 & 21.8 & 18.4 & 0.57 & 0.19 & 0.01 & $<0.01$ & $<0.01$ \\
\hline PUN, mg/dL & 27.6 & 22.6 & 27.1 & 27.8 & 15.54 & 0.85 & 0.02 & 0.78 & 0.03 \\
\hline FE, kg milk/ kg DMI & 1.63 & 1.58 & 1.74 & 1.59 & 0.04 & 0.11 & 0.95 & 0.04 & 0.56 \\
\hline NUE & 0.27 & 0.27 & 0.31 & 0.29 & 0.01 & 0.02 & 0.27 & 0.21 & 0.91 \\
\hline
\end{tabular}

${ }^{1}$ GC-HRUP: Diet corn high RUP; GC-LRUP: Diet corn low RUP; DCP-HRUP: Diet citrus pulp high RUP; DCPLRUP: Diet citrus pulp low RUP.

${ }^{2}$ FCM3.5: Fat correct milk 3.5\% of milk fat; MUN: Milk urea nitrogen; PUM: Plasma urea nitrogen; FE: Feed efficiency (TDMI/MILK); NUE: Nitrogen use efficiency ( $\mathrm{kg} \mathrm{N}$ in milk/ kg N consumed).

${ }^{3}$ Standard error of mean.

Fat corrected milk tended $(\mathrm{P}=0.08)$ to be greater in animals fed with DCP-LRUP diet compared to animals fed with GC-LRUP diet. The milk fat concentration and production were significantly higher in DCP-LRUP group. The non-starch ingredients have higher cation exchange capacity than ingredients rich in starch. This property is explained by their ability to attract and bind hydrogen ions (McBurney et al., 1983). Based on that we hypothesize that lower rumen $\mathrm{pH}$ may have occur in GC-HRUP fed animals, which may lead to incomplete biohydrogenation of fatty acids and production of intermediary products such as trans-10, cis-12 CLA which can inhibit fat synthesis in the mammary gland (Bauman and Griinari, 2003). Furthermore, DCP diets have 
high NDF content, good ruminal digestibility compared to ground corn, promoting greater ruminal acetate production. This volatile fatty acid is the main precursor of fat in the mammary gland (Bauman and Griinari, 2003).

The concentration of protein was greater $(\mathrm{P}=$ 0.001) for GC treatments, regardless of RUP content. Garcia et al. (2010), studying Holstein cows in a rotational grazing system also found lower protein yield in cows supplemented with citric pulp in comparison to ground corn. This result can be explained by the high production of microbial protein from rumen microorganisms, that might result in a greater amount of metabolizable protein that reach the intestine (Hall et al., 2010).

Diets with more starch usually result in greater ruminal propionate concentration than diets with pectin from the citric pulp (Broderick et al., 2002). Carbohydrates rapidly fermented like starch have been associated to greater milk protein contents due to high available energy and a greater amount of microbial protein produced (Jenkins and Gure, 2005).

The treatments with citric pulp presented lower values of milk urea nitrogen (MUN) compared to those supplemented with corn $(\mathrm{P}<0.05)$. DCPHRUP had lower values of MUN when compared with DCP-LRUP. This might be associated to higher synchronism between energy and soluble $\mathrm{CP}$ and NPN coming from the pasture. Citrus pulp has higher soluble sugar content and higher degradation rate in comparison to ground corn which may resulted in better use of the $\mathrm{N}$ available in the rumen, and then lower concentrations of urea in the milk. Lower energy availability in the rumen can limit the use of nitrogen produced during the ruminal fermentation and causes an increase in ammonia absorption and therefore MUN (Sutton et al., 1987).

The animals fed with GC-LRUP diet were more efficient for feed efficiency $(1.74 \mathrm{~kg} / \mathrm{kg})$ and nitrogen use $(0.31 \mathrm{~kg} / \mathrm{kg})$. This fact occurred due to the lower dry matter intake without compromising milk production for this treatment. As the diet provided a greater amount of ruminal degradable protein in comparison to the GCHRUP and DCP-HRUP treatments, and higher availability of starch, the treatment allowed better use of the nutrients in the diet by the animals.

In a meta-analysis Huntanen and Hristov (2009) reported that the mean values for feed efficiency in the USA and Europe were $1.42 \mathrm{~kg} / \mathrm{kg}$, which were inferior to those obtained in this study. Danes et al. (2013), working with crossbred Jersey $\mathrm{x}$ Holstein, in a rotational pasture system with elephant pasture, obtained EUN values $(\mathrm{kg} / \mathrm{kg})$ of 19.2 and 18.2 in diets with 168 and $184 \mathrm{~g} / \mathrm{kg} \mathrm{CP}$, respectively.

The concentration of creatine and purine derivatives are presented in Table 5. Balcells et al. (1996) proposed that excreted purine derivatives are exclusively derived from the intestinal degradation of microbial nucleic acids. The adenine and guanine bases are catabolized and proportionally excreted in the urine as purine derivatives, mostly allantoin and Xanthine, hypoxanthine and uric acid. Thus, a nondifference in these parameters between the treatments would indicate no difference in the synthesis of microbial protein in the rumen.

Table 5. Concentration of purine derivatives and Purine/creatinine ratio of Holstein X Gyr (F1) cows in rotational grazing Panicum maximum cv. Mombaça fed with different non-fiber carbohydrates sources in diets with high or low rumen-undegradable protein content

\begin{tabular}{|c|c|c|c|c|c|c|c|c|c|}
\hline \multirow{3}{*}{ Item } & \multicolumn{4}{|c|}{ Diets $^{1}$} & \multirow{3}{*}{ SEM $^{1}$} & \multicolumn{4}{|c|}{$P$-value } \\
\hline & $\begin{array}{c}\text { GC } \\
\text { HRUP }\end{array}$ & $\begin{array}{c}\text { DCP } \\
\text { HRUP }\end{array}$ & GC & $\begin{array}{l}\text { DCP } \\
\text { RUP }\end{array}$ & & $\begin{array}{l}\text { RUP } \\
\text { X GC }\end{array}$ & RUP X & $\begin{array}{l}\text { NFC X } \\
\text { IRUPP }\end{array}$ & $\begin{array}{l}\text { NFC X } \\
\text { HRUP }\end{array}$ \\
\hline & HRUP & HRUP & LRUP & LRUP & & $\mathrm{X} \mathrm{GC}$ & DCP & LRUP & HRUP \\
\hline Uric acid $\mathrm{mmol} / \mathrm{L}$ & 1.43 & 1.38 & 1.51 & 1.56 & 0.095 & 0.56 & 0.19 & 0.67 & 0.75 \\
\hline Creatinine $\mathrm{mmol} / \mathrm{L}$ & 3.66 & 3.60 & 3.70 & 3.51 & 0.140 & 0.85 & 0.65 & 0.36 & 0.79 \\
\hline Alantoin $\mathrm{mmol} / \mathrm{L}$ & 12.21 & 12.76 & 12.34 & 12.08 & 0.712 & 0.90 & 0.75 & 0.46 & 0.58 \\
\hline Alantoin/creatine & 3.51 & 3.65 & 3.46 & 3.74 & 0.172 & 0.87 & 0.71 & 0.27 & 0.56 \\
\hline
\end{tabular}

${ }^{1}$ GC-HRUP: Diet corn high RUP; GC-LRUP: Diet corn low RUP; DCP-HRUP: Diet citrus pulp high RUP; DCPLRUP: Diet citrus pulp low RUP. 
Danés et al. (2013) also found no difference in the urine purine derivatives production of crossbreed Holstein $\mathrm{x}$ Jersey cows under rotational grazing management, with increasing $\mathrm{CP}$ levels in the concentrate. These data support the hypothesis that increases in rumen degradable protein levels did not always result in an increase in the production of microbial protein. Voelker et al. (2003) found a decrease in the microbial nitrogen flow to the small intestine, when high moisture ground corn was replaced by citrus pulp, data that not agree with our results.

\section{CONCLUSIONS}

Changes in dietary NFC source and degradability of dietary protein did not alter milk production in lactating dairy cows. The use of starch as NFC source could increase the milk protein content regardless of the dietary RUP concentration. The use of citrus pulp as a carbohydrate source could be a strategy to increase the dry matter intake and the milk fat content of cows under a rotational grazing system.

\section{REFERENCES}

AOAC INTERNACIONAL., 2012. Official Methods of Analysis. 19th ed. AOAC International, Gaithersburg, MD.

ALLEN, M.S.; BRADFORD, B.J.; OBA, M. Board-invited review: the hepatic oxidation theory of the control of feed intake and its application to ruminants. J. Anim. Sci., v.87. p.3317-3334, 2009.

ALVIM, M.J.; XAVIER, D.F.; VERNEQUE, R.S.; BOTREL, M.A. Resposta do Tifton 85 a doses de nitrogênio e intervalos de cortes. Pesqui. Agropecu. Bras., v.34, p.2345-2352, 1999.

ANIL, M.H.; MBANYA, J.N.; SYMONDS, H.W.; FORBES, J.M. Responses in the voluntary intake of hay or silage by lactating cows to intraruminal infusions of sodium acetate or sodium propionate, the tonicity of rumen fluid or rumen distension. Br. J. Nutr., v.69, p.699-712, 1993.

BALCELLS, J.; GUADA, J.A.; CASTRILLO, C. Determination of rumen microbial-nitrogen production in sheep: a comparison of urinary purine excretion with methods using $15 \mathrm{~N}$ and purine bases as markers of microbial-nitrogen entering the duodenum." Br. J. Nutr. v.75, p.699$709,1996$.
BALSALOBRE, M.A.A.; CORSI, M.; SANTOS, P.M. et al. Composição química e fracionamento do nitrogênio e dos carboidratos do capimtanzânia irrigado sob três níveis de resíduo póspastejo. Rev. Bras. Zootec., v.32, p.519-528, 2003.

BAMPIDIS, V.A.; ROBINSON, P.H. Citrus byproducts as ruminant feeds: a review. Anim. Feed Sci. Technol., v.128, p.175-217, 2006.

BARGO, F.; MULLER, L.D.; KOLVER, E.S.; DELAHOY, J.E. Invited review: Production and digestion of supplemented dairy cows on pasture. J. Dairy Sci., v.86, p.1-42, 2003.

BARROS, E.E.L.; FONTES, C.A.A.; VIEIRA, E.D.R.A.M. et al. Biases in fecal excretion estimation by using internal markers and chromic oxide in digestion trials with ruminants. Rev. Bras. Zootec., v.38, p.2015-2020, 2009.

BAUMAN, D.E.; GRIINARI, J.M. Nutritional regulation of milk fat synthesis. Annu. Rev. Nutr., v.23, p.203-227, 2003 .

BEN-GHEDALIA, D.; YOSEF, E.; MIRON, J.; EST, Y. The effects of starch- and pectin-rich diets on the quantitative aspects of digestion in sheep. Anim. Feed Sci. Technol., v.24, p.289-298, 1989.

BRITO, A.F.; SODER, K.J.; CHOUINARD, P.Y. et al. Production performance and milk fatty acid profile in grazing dairy cows offered ground corn or liquid molasses as the sole supplemental nonstructural carbohydrate source. J. Dairy Sci., v.100, p.8146-8160, 2017.

BRODERICK, G.A.; MERTENS, D.R.; SIMONS, R. Efficacy of carbohydrate sources for milk production by cows fed diets based on alfalfa silage. J. Dairy Sci., v.85, p.1767-1776, 2002.

BUCKNER, C.D.; KLOPFENSTEIN, T.J.; ROLFE, K.M. et al. Ruminally undegradable protein content and digestibility for forages using the mobile bag in situ technique. J. Anim. Sci., v.91 p.2812-2822, 2013.

BURNS, J.C.; POND, K.R.; FISHER, D.S. Measurement of forage intake. In: FAHEY, Jr. G.C.; COLLINS, M.; MERTENS, D.R. et al. (Eds.) Forage quality, evaluation, and utilization. Madison: ASA, CSSA, SSSA, 1994. p.494-526. 
CÂNDIDO, M.J.D.; ALEXANDRINO, E.; GOMIDE, C.A.M. et al. Período de descanso, valor nutritivo e desempenho animal em pastagem de Panicum maximum cv. Mombaça sob lotação intermitente. Rev. Bras. Zootec., v.34, p.14591467,2005 .

CASTAGNARA, D.D.; MESQUITA, E.E.; NERES, M.A. et al. Valor nutricional e características estruturais de gramíneas tropicais sob adubação nitrogenada. Arch. Zootec., v.60, p.931-942, 2011.

CHEN, X.B.; GOMES, M.J. Estimation of microbial protein supply to sheep and cattle based on urinary excretion of purine derivatives - an overview of technical details. Aberdeen, UK: International Feed Research Unit / Rowett Research Institute, 1992. 21p.

CHIZZOTTI, M.L.; VALADARES FILHO, S.C.; VALADARES, R.F.D. Excreção de creatinina em vacas. In: REUNIÃO ANUAL DA SOCIEDADE BRASILEIRA DE ZOOTECNIA, 41., 2004, Campo Grande. Anais... Campo Grande: SBZ, 2004.

CHIZZOTTI, M.L.; VALADARES FILHO, S.C.; VALADARES, R.F.D.; CHIZZOTTI, F.H.M.; TEDESCHI L.F. Determination of creatinine excretion and evaluation of spot urine sampling in Holstein cattle. Liv. Sci., v.113, p.218-225, 2008.

CLARK, P.W.; ARMENTANO L.E. Influence of particle size on the effectiveness of beet pulp fiber. J. Dairy Sci., v.80, p.898-904, 1997.

COLOMBINI, S., BRODERICK G.A. and CLAYTON, M.K. Effect of quantifying peptide release on ruminal protein degradation determined using the inhibitor in vitro system. $J$. Dairy Sci., v.94. p.1967-1977, 2011.

DANES, M.A.C.; CHAGAS, L.J.; PEDROSO, A.M.; SANTOS, F.A.P. Effect of protein supplementation on milk production and metabolism of dairy cows grazing tropical grass. J. Dairy Sci., v.96, p.407-419, 2013.

EUCLIDES, V.P.B.; MACEDO, M.C.M.; ZIMMER, A.H. et al. Avaliação dos capins mombaça e massai sob pastejo. Rev. Bras. Zootec., v.37, p.18-26, 2008.

FREDIN, S.M.; AKINS, M.S.; FERRARETTO, L.F.; SHAVER, R.D. Effects of corn-based diet starch content and neutral detergent fiber source on lactation performance. digestibility. and bacterial protein flow in dairy cows. J. Dairy Sci., v.98, p.554-565, 2015.
FREITAS, H.P.; LAGE, C.F.A.; MALACCO, V.M.R. et al. Partial substitution of soybean meal with a yeast-derived protein in the diet of dairy cows under a rotational grazing system. Liv. Sci., v.225, p.144-150, 2019.

GAINES, W.L. The energy basis of measuring milk yield in dairy cows. Bulletin, n.308, p.403438, 1928. (Agricultural Experiment Station).

GARCÍA, G.A.; REIS, R.B.; PEREIRA, A.B.D. et al. Produção e composição do leite de vacas em pastagem de capim-elefante (Pennisetum purpureum) suplementado com diferentes fontes de carboidratos. Arq. Bras. Med. Vet ., v.62, p.875-882, 2010.

GROVUM, W.L. Mechanisms explaining the effects of short chain fatty acids on feed intake in ruminants-osmotic pressure. insulin and glucagon. In: ENGLISH INTERNATIONAL SYMPOSIUM ON RUMINANT PHYSIOLOGY, 1995, Stuttgart. Proceedings... Stuttgart, Germany: [s.n.], 1995.

DANES, M.D.A.C.; CHAGAS, L.J.; PEDROSO, A.M.; SANTOS, F.A.P. Effect of protein supplementation on milk production and metabolism of dairy cows grazing tropical grass. J. Dairy Sci., v.96, p.407-419, 2013.

HALL, M.B.; LARSON, C.C.; WILCOX, C.J. Carbohydrate source and protein degradability alter lactation. ruminal and blood measures. $J$. Dairy Sci., v.93, p.311-322, 2010.

HATFIELD, R.D.; WEIMER, P.J. Degradation characteristics of isolated and in situ cell wall lucerne pectic polysaccharides by mixed ruminal microbes J. Sci. Food Agric., v.69, p.185-196, 1995.

HRISTOV, A.N.; ROPP, J.K. Effect of dietary carbohydrate composition and availability on utilization of ruminal ammonia nitrogen for milk protein synthesis in dairy cows. J. Dairy Sci., v.86, p.2416-2427, 2003.

HUNTANEN, P.; HRISTOV, A.N. A metaanalysis of the effects of dietary protein concentration and degradability on milk protein yield and milk $\mathrm{N}$ efficiency in dairy cows. $J$. Dairy Sci., v.92, p.3222-3232, 2009.

JENKINS, T.C. GUIRE, M.A. Effects of nutrition on milk composition: a 25-year review of research reported in the journal of Journal of Dairy Science. In: ANNUAL TRI-STATE DAIRY CONFERENCE, 2005. Proceedings... [s.l.]: [s.n.], 2005. p.51-60 
LICITRA， G.; HERNANDEZ， T.M.; VAN SOEST, P.J. Standardization of procedures for nitrogen fractionation of ruminant feeds. Anim. Feed Sci. Tec., v.57, p.347-358, 1996.

MAGALHÃES, K.A., VALADARES FILHO, S.C.; VALADARES, R.F.D. et al. Produção de proteína microbiana, concentração plasmática de ureia e excreções de ureia em novilhos alimentados com diferentes níveis de ureia ou casca de algodão. Rev. Bras. Zootec., v.34, p.1400-1407, 2005.

MCBURNEY, P.J.; MICHAEL, I.; VAN SOEST, L.; CHASE. E. Cation exchange capacity and buffering capacity of neutral-detergent fibres. $J$. Sci. Food Agric., v.34, p.910-916, 1983.

MULLIGAN, F.J.; DILLON, P.; CALLAN, J.J. et al. Supplementary concentrate type affects nitrogen excretion of grazing dairy cows. J. Dairy Sci., v.87, p.3451-3460, 2004.

NUTRIENTS requirements of dairy cattle. 7.ed. Washington: National Academic Science, 2001.

OFFICIAL methods of analysis. 15.ed. Arlington: AOAC International, 1990.

OLIVEIRA, M.C.P., SILVA, N.M.A., BASTOS, L.P.F. et al. Fourier Transform Infrared Spectroscopy (FTIR) for MUN analysis in normal and adulterated Milk. Arq. Bras. Med. Vet. Zoo., v.64, p.1360-1366, 2012.

PENATI, M.A. Estudo do desempenho animal e produção do capim-tanzânia (Panicum maximum Jacq.) em um sistema rotacionado de pastejo sob irrigação em três níveis de resíduo pós-pastejo. 2002. Dissertação (Mestrado) - Escola Superior de Agricultura "Luiz de Queiroz", Universidade de São Paulo, Piracicaba, SP.

REIS, R.B.; COLOMBINI, S.; MILLER, A. et al. Protein fractions and rates of degradation of tropical forages from intensively grazed pastures. In: EUROPEAN FEDERATION OF ANIMAL SCIENCE INTERNATIONAL SYMPOSIUM ON ENERGY AND PROTEIN METABOLISM AND NUTRITION, 3., 2010, Parma. Proceedings... Parma: EAAP, 2010. p.717-718.
SALIBA, E.O.S.; FARIA, E.P.; RODRIGUEZ, N.M. Use of Infrared Spectroscopy to Estimate Fecal Output with Marker LIPE®. Int. J. Food Sci. Nut., v.1, p.1-10, 2015.

SAS INSTITUTE. User's Guide: Statistics. Version 9.01. SAS Institute Inc, Cary, NC, 2001.

SCHOR, A.; GAGLIOSTRO, G.A. Undegradable protein supplementation to early-lactation dairy cows in grazing conditions. J. Dairy Sci., v.84, p.1597-1606, 2001.

SILVA, R.C. Suplementação da dieta de vaca leiteira mantidas em pastagens com virginimicina e soja crua ou tostada. 2013. 57f. Dissertação (Mestrado) - Universidade Estadual de São Paulo, Piracicaba, SP.

SUTTON, J.D.; BINES, J.A.; MORANT, S.V. et al. A comparison of starchy and fibrous concentrates for milk production, energy utilization and hay intake by Friesian cows. $J$. Agric. Sci,.v.109, p.375-386, 1987.

VAN SOEST, P.J.; ROBERTSON, J.B.; LEWIS, B.A. Symposium: carbohydrate methodology, metabolism, and nutritional implications in dairy cattle. Methods for dietary fiber neutral detergent fiber and non-starch polysaccharides in relation to animal nutrition. J. Dairy Sci., v.74, p.3583-3597, 1991.

VAN VUUREN, A.M.; VAN DER KOELEN, C.J.; VROONS-DE BRUIN, J. Ryegrass versus corn starch or beet pulp fiber diet effects of digestion and intestinal amino acids in dairy cows. J. Dairy Sci., v.76, p.2692-2700, 1993.

VOELKER, J.A.; ALLEN, M.S. Pelleted beet pulp substituted for high-moisture corn: 3 . Effects on ruminal fermentation, $\mathrm{pH}$, and microbial protein efficiency in lactating dairy cows. J. Dairy Sci., v.86, p.3562-3570, 2003. 